\title{
Sistem Pendukung Keputusan Pemilihan Pegawai Pemerintah Non Pegawai Negeri (PPNPN) Terbaik Pada Kantor Imigrasi Kelas I Polonia Medan Menerapkan Metode Multifactor Evaluation Process (MFEP)
}

\author{
Muhammad Wirza Pratama Agatmadja*, Surya Darma Nasution \\ Prodi Teknik Informatika, STMIK Budi Darma, Medan, Indonesia \\ Email: 1," wirzapratamaagtmadja@gmail.com, ${ }^{2}$ suryadarma@ stmik-budidarma.ac.id \\ Email Penulis Korespondensi wirzapratamaagtmadja@gmail.com \\ Submitted 08-05-2020; Accepted 01-06-2020; Published 14-06-2020
}

\begin{abstract}
Abstrak
Proses pengambilan keputusan pemilihan pegawai pemerintah non pegawai negeri (ppnp) terbaik masih dilakukan secara manual, dimana dalam pemilihan masih sering terdapat beberapa pegawai pemerintah non pegawai negeri (ppnpn) yang tidak sesuai seperti yang diinginkan oleh pihak instansi, sehingga dalam pemilihan masih adanya ketidak sesuaian dengan prosedur yang ada, maka dari itu diperlukannya sistem pendukung keputusan yang nantinya akan membantu dalam proses pengambilan keputusan. Sistem pendukung keputusan merupakan sebuah sistem yang dapat digunakan untuk mendukung para pengambil keputusan dengan alternatif terbaik dalam mengambil keputusan proses pemilihan pegawai pemerintah non pegawai negeri (ppnpn) pada Kantor Imigrasi Kelas I Polonia. Metode Multifactor Evaluation Process (MFEP) merupakan metode yang cukup sederhana yang dapat digunakan pada pengambilan keputusan untuk menganalisa multi kriteria. Metode ini nantinya akan mengambil keputusan dengan beberapa kriteria yang saling bertentangan dengan alternatif dan akan menghasilkan nilai terbesar yang akan terpilih sebagai alternatif terbaik. Hasil perhitungan dari metode ini akan sesuai harapan apabila alternatif yang terpilih memenuhi kriteria yang telah ditentukan. Dengan demikian sistem pendukung keputusan sangat dibutuhkan agar dapat membantu mengambil keputusan yang tepat dalam pemilihan pegawai pemerintah non pegawai negeri (ppnpn) terbaik pada Kantor Imigrasi Kelas I Polonia. Dalam sistem pendukung keputusan ada beberapa metode yang dapat digunakan untuk menyelesaikan suatu permasalahan dalam mengambil keputusan.
\end{abstract}

Kata Kunci: SPK, MFEP,Terbaik, PPNPN..

\begin{abstract}
The decision making process for the selection of the best non-civil servant government employees is still done manually, where in the election there are still often some non-civil servant government employees (ppnpn) that are not appropriate as desired by the agency, so that in the election there are still nonconformities with existing procedures, therefore the need for a decision support system that will later assist in the decision making process. Decision support system is a system that can be used to support decision makers with the best alternative in making decisions in the process of selecting non-civil servant government employees (PPNPN) at the Polonia Class I Immigration Office. The Multifactor Evaluation Process (MFEP) method is a fairly simple method that can be used in decision making to analyze multiple criteria. This method will make decisions with several criteria that conflict with each other and will produce the greatest value that will be selected as the best alternative. The results of the calculation of this method will be as expected if the chosen alternative meets the specified criteria. Thus a decision support system is needed so that it can help make the right decision in the selection of the best non civil servant government employees (PPNPN) at the Polonia Class I Immigration Office. In a decision support system there are several methods that can be used to solve a problem in making a decision.
\end{abstract}

Keywords: SPK, MFEP, Best, PPNPN

\section{PENDAHULUAN}

Pegawai Pemerintah Non Pegawai Negeri (PPNPN) merupakan nama lain daripada honorer yang diakui oleh Pemerintah dan Negara yang diperbantukan di suatu instansi untuk membantu suatu pekerjaan pada unit yang membutuhkan, salah satunya adalah Kantor Imigrasi Kelas I Polonia. Kantor Imigrasi Kelas I Polonia merupakan kantor pelayanan jasa pembuatan paspor bagi warga negara Indonesia (WNI) dimana paspor ini berfungsi sebagai akses keluar masuk ke negara lain sekaligus juga sebagai identitas warga negara Indonesia (WNI) yang berpergian keluar negeri.

Dimana dalam pemilihan Pegawai Pemerintah Non Pegawai Negeri (PPNPN) terbaik penulis melihat masih adanya ketidak sesuaian dengan prosedur yang ada dalam pemilihan pegawai terbaik, sehingga membuat pegawai yang memenuhi kriteria untuk menjadi pegawai terbaik mengalami kecemburuan sosial, dimana pemilihan pegawai terbaik ini adalah moment yang paling ditunggu bagi para Pegawai Pemerintah Non Pegawai Negeri (PPNPN) karena jika memenuhi kriteria pegawai tersebut akan mendapatkan suatu bonus tambahan, yang diambil dari potongan gaji para pegawai yang bermasalah atau yang tidak sesuai dengan prosedur dan pemilihan ini dilakukan dengan kurun waktu kurang lebih 3 bulan sekali.

Berdasarkan penelitian terdahulu Iis Afrianty [1], bahwa Sistem Pendukung Keputusan (SPK) seleksi penerima zakat untuk menentukan kelayakan calon penerima zakat menerapkan metode Multifactor Evaluation Process (MFEP) dapat memberikan rekomendasi peringkat keputusan dari penyeleksian para calon penerima zakat. Berdasarkan pengujian menggunakan blackbox memberikan hasil akhir berupa rangking mustahik berdasarkan nilai setiap mustahik. Sedangkan pengujian dari penyebaran kuisioner kepada pengguna (User Acceptance Test) menggunakan skala likert menghasilkan nilai sebesar $87,87 \%$ dan di interprestasikan sebagai sangat baik, dan berdasarkan penelitian terdahulu Rifa Turaina [2], bahwa peranan sistem komputerisasi yang ditunjang dengan penggunaan aplikasi bahasa pemrograman, akan lebih efektif dan efisien serta mempunyai nilai tambah bila dibanding dengan sistem manual. Dengan menggunakan sistem komputerisasi maka proses transaksi cepat dan efisien sehingga informasi yang dibutuhkan dapat dilihat setiap saat dengan mudah dan kapanpun jika dibutuhkan serta penyimpanan data terjamin aman. Dengan adanya sistem Penunjang Keputusan Seleksi 
Penerimaan Calon Tenaga Honorer yang diajukan telah membantu Kepala Sekolah dalam menerima informasi penerimaan calon Tenaga Honorer dengan cepat dan tepat, output atau laporan-laporan yang dihasilkan pada sistem ini lebih jelas dan terinci.

\section{METODE PENELITIAN}

\subsection{Sistem Pendukung Keputusan}

Sistem Pendukung Keputusan / Decision Support System (DSS) merupakan suatu sistem atau informasi yang menyediakan informasi, pemodelan dan pemanipulasian data untuk melakukan suatu proses pengambilan keputusan yang dilakukan oleh pelaku bisnis untuk pengambilan keputusan dalam situasi yang semi terstruktur dan situasi yang tidak terstruktur sehingga dapat memudahkan pihak-pihak yang ingin mengambil suatu keputusan dengan mudah dan akurat[3]-[7].

\subsection{Pegawai Pemerintah Non Pegawai Negeri (PPNPN) / Honorer}

PPNPN / Honorer adalah seseorang yang diangkat oleh pejabat Pembina kepegawaian atau pejabat lain dalam pemerintahan untuk melaksanakan tugas-tugas tertentu pada instansi pemerintahan dan penghasilannya menjadi beban APBD/APBN.

\subsection{Metode Multifactor Evaluation Process (MFEP)}

Multifactor Evaluation Process (MFEP) merupakan model pengambilan keputusan yang menggunakan pendekatan kolektif dari proses pengambilan keputusannya [8]. Adapun langkah-langkah dalam proses perhitungan menggunakan metode MFEP adalah sebagai berikut :

1. Menentukan faktor dan bobot faktor dimana total pembobotan harus sama dengan satu.

2. Mengisikan nilai untuk setiap faktor yang mempengaruhi dalam pengambilan keputusan dari data-data yang akan diproses, nilai yang dimasukkan dalam proses pengambilan keputusan dari data-data yang akan diproses, nilai yang dimasukkan dalam proses pengambilan keputusan merupakan nilai objektif.

3. Proses perhitungan weight evaluation yang merupakan proses perhitungan bobot antara faktor weight evaluation untuk memperoleh total hasil evaluasi

Berikut ini adalah rumusan total hasil evaluasi ditunjukan oleh persamaan (1), yaitu :

$W=\mathrm{w}_{1}+\mathrm{w}_{2}+\mathrm{w}_{3}+\cdots \cdots+\mathrm{w}_{\mathrm{n}}$

Ket :

$W=$ Total Bobot Kriteria

$\mathrm{W}=$ Bobot Kriteria

Rumus bobot kriteria ditunjukkan oleh persamaan (2), yaitu :

$W e=$ Evaluasi Bobot

$W=$ Bobot Kriteria

e = Evaluasi Kriteria

Pada metode Multifactor Evaluation Process (MFEP), dimana dalam hasil perhitungan alternatif yang tertinggi maka akan terpilih sebagai Pegawai Pemerintah Non Pegawai Negeri (PPNPN) terbaik..

\section{HASIL DAN PEMBAHASAN}

Berdasarkan analisa masalah yang ada, pihak Kantor Imigrasi Kelas I Polonia untuk melakukan pemilihan pegawai terbaik agar tidak mengecewakan pihak instansi dan tidak menimbulkan kecemburuan sosial pada pegawai yang memenuhi kriteria untuk menjadi pegawai terbaik. Dimana rancangan sistem dalam pemilihan pegawai terbaik yang akan dirancang oleh penulis adalah berdasarkan kriteria dalam segi Kedisiplinan, Kerajinan, Etika dan Penilaian Pejabat yang bersangkutan. Selain membantu pihak instansi, sistem ini juga dapat menampilkan perolehan nilai-nilai terhadap kriteria seperti Kedisiplinan, Kerajinan, Etika dan Penilaian Pejabat.

1. Data Alternatif

Untuk Sistem Pendukung Keputusan Pemilihan Pegawai Pemerintah Non Pegawai Negeri (PPNPN) Terbaik Pada Kantor Imigrasi Kelas I Polonia dengan menerapkan metode Multifaktor Evaluation Process, penulis juga memiliki beberapa data pegawai yang akan dijadikan data alternatif, adapun data alternatif tersebut adalah sebagai berikut :

Tabel 1. Data Alternatif

\begin{tabular}{clc}
\hline No & \multicolumn{1}{c}{ Nama } & Unit/ Kantor \\
\hline 1 & Ahmad Roihan Sembiring & Imigrasi Kelas I Medan \\
2 & Andi Suandi & Imigrasi Kelas I Medan \\
3 & Budi Setiawan & Imigrasi Kelas I Medan \\
4 & Feriwani & Imigrasi Kelas I Medan \\
5 & Immas Sariwijaya & Imigrasi Kelas I Medan \\
6 & Juanda Alwi & Imigrasi Kelas I Medan \\
7 & Kaspi Ikhwan & Imigrasi Kelas I Medan \\
\hline
\end{tabular}




\begin{tabular}{clc}
\hline 8 & Markus Simamora & Imigrasi Kelas I Medan \\
9 & Maulana & Imigrasi Kelas I Medan \\
10 & Muhammad Ilham Batubara & Imigrasi Kelas I Medan \\
11 & Muhammad Rasid Lubis & Imigrasi Kelas I Medan \\
12 & Muhammad Wirza Pratama Agatmadja & Imigrasi Kelas I Medan \\
13 & Ratini & Imigrasi Kelas I Medan \\
14 & Roy Mike Andros ZakariaPardede & Imigrasi Kelas I Medan \\
15 & Sugeng Apri Lukti & Imigrasi Kelas I Medan \\
16 & Sugeng Prasetyo & Imigrasi Kelas I Medan \\
17 & Tedijaya Iskandar & Imigrasi Kelas I Medan \\
\hline
\end{tabular}

2. Menentukan Kriteria Dan Bobot

Metode Multifactor Evaluation Process dalam prosesnya diperlukan kriteria yang akan dijadikan bahan perhitungan pada proses perangkingan Pemilihan Pegawai Pemerintah Non Pegawai Negeri (PPNPN) Terbaik Pada Kantor Imigrasi Kelas I Polonia. Kriteria yang menjadi bahan pertimbangan adalah sebagai berikut:

Tabel 2. Data Kriteria

\begin{tabular}{lll}
\hline No & Kriteria & Keterangan \\
\hline 1 & C1 & Kedisiplinan \\
2 & C2 & Kerajinan \\
3 & C3 & Etika \\
4 & C4 & Penilaian Pejabat \\
\hline
\end{tabular}

Tabel 3. Bobot

\begin{tabular}{ll}
\hline Bilangan Fuzzy & Nilai \\
\hline Sangat Buruk (SBK) & 20 \\
Buruk (BK) & 40 \\
Cukup (C) & 60 \\
Baik (B) & 80 \\
Sangat Baik (SB) & 100 \\
\hline
\end{tabular}

Tabel 4. Nilai Absensi

\begin{tabular}{lll}
\hline Absensi & Keterangan & Nilai \\
\hline Tepat Waktu & Sangat Baik & 100 \\
Tidak Tepat Waktu & Buruk & 50 \\
\hline
\end{tabular}

Tabel 5. Nilai Ketaatan

\begin{tabular}{lll}
\hline Ketaatan & Keterangan & Nilai \\
\hline Taat & Sangat Baik & 100 \\
Tidak Taat & Buruk & 50 \\
\hline
\end{tabular}

Tabel 6. Nilai Kebersihan

\begin{tabular}{ccc}
\hline Kebersihan & Keterangan & Nilai \\
\hline Bersih & Sangat Baik & 100 \\
Tidak Bersih & Buruk & 50 \\
\hline
\end{tabular}

Tabel 7. Nilai Kerapian

\begin{tabular}{ccc}
\hline Kerapian & Keterangan & Nilai \\
\hline Rapi & Sangat Baik & 100 \\
Tidak Rapi & Buruk & 50 \\
\hline
\end{tabular}

Tabel 8. Nilai Komunikasi

\begin{tabular}{lll}
\hline Komunikasi & Keterangan & Nilai \\
\hline Baik & Sangat Baik & 100 \\
Cukup Baik & Cukup & 65 \\
Tidak Baik & Buruk & 30 \\
\hline
\end{tabular}

Tabel 9. Nilai Perilaku

\begin{tabular}{lll}
\hline Perilaku & Keterangan & Nilai \\
\hline Baik & Sangat Baik & 100 \\
Cukup Baik & Cukup & 65 \\
\hline
\end{tabular}




\begin{tabular}{lll}
\hline Tidak Baik & Buruk & 30 \\
\hline \multicolumn{2}{c}{ Tabel 10. } & Nilai Kasi \\
\hline Komunikasi & Keterangan & Nilai \\
\hline Baik & Sangat Baik & 100 \\
Cukup Baik & Cukup & 65 \\
Tidak Baik & Buruk & 30 \\
\hline
\end{tabular}

Tabel 11. Nilai Kasubag

\begin{tabular}{lll}
\hline Perilaku & Keterangan & Nilai \\
\hline Baik & Sangat Baik & 100 \\
Cukup Baik & Cukup & 65 \\
Tidak Baik & Buruk & 30 \\
\hline
\end{tabular}

Tabel 12. Nilai Bobot

\begin{tabular}{lll}
\hline No & Kriteria & Bobot $(\mathbf{W})$ \\
\hline 1 & Kedisiplinan & $30 \%$ \\
2 & Kerajinan & $25 \%$ \\
3 & Etika & $25 \%$ \\
4 & Penilaian Pejabat & $20 \%$ \\
\hline
\end{tabular}

Sehingga $\mathrm{W}=(0.3,0.25,0.25,0.2)$ dan $\mathrm{N}=4$

Tabel 13. Rating Kecocokan

\begin{tabular}{llllll}
\hline No & Nama & Kedisiplinan & Kerajinan & Etika & Penilaian Pejabat \\
\hline 1 & Sugeng Apri Lukti & 50 & 100 & 100 & 65 \\
2 & Maulana & 75 & 100 & 65 & 82.5 \\
3 & Roy Mike Andros Zakaria Pardede & 100 & 50 & 82.5 & 100 \\
4 & Markus Simamora & 75 & 100 & 65 & 100 \\
5 & Juanda Alwi & 75 & 100 & 65 & 65 \\
6 & Muhammad Rasid Lubis & 100 & 100 & 65 & 65 \\
7 & Muhammad Ilham Batubara & 100 & 100 & 82.5 & 30 \\
8 & Muhammad Wirza Pratama Agatmadja & 100 & 100 & 100 & 82.5 \\
9 & Immas Sariwijaya & 100 & 75 & 100 & 100 \\
10 & Feriwani & 100 & 75 & 65 & 100 \\
11 & Ahmad Roihan Sembiring & 100 & 100 & 100 & 82.5 \\
12 & Zaenal Abidin & 100 & 100 & 82.5 & 82.5 \\
13 & Ratini & 100 & 75 & 82.5 & 82.5 \\
14 & Kaspi Ikhwan & 100 & 75 & 82.5 & 100 \\
15 & Tedijaya Iskandar & 100 & 75 & 100 & 100 \\
16 & Budi Setiawan & 100 & 100 & 100 & 100 \\
17 & Sugeng Prasetyo & 75 & 100 & 47.5 & 100 \\
18 & Andi Suandi & 75 & 100 & 30 & 100 \\
\hline
\end{tabular}

Adapun beberapa tahapan-tahapan serta perumusan dalam penerapan moetode Multifaktor Evaluation Process (MFEP), adalah sebagai berikut :

1. Menentukan faktor dan bobot faktor dimana total pembobotan harus sama dengan $1(\Sigma$ pembobotan $=1)$, yaitu factor weight.

2. Mengisikan nilai untuk setiap faktor yang mempengaruhi dalam pengambilan keputusan dari data - data yang akan diproses, nilai yang dimasukkan dalam proses pengambilan keputusan merupakan nilai objektif, yaitu sudah pasti yaitu, factor evaluation yang nilaianya antara $0-1$.

3. Proses perhitungan nilai Weighting evaluation yang merupakan proses perhitungan bobot antara factor weight dan factor evaluation dengan serta penjumlahan seluruh hasil weight evaluations untuk memperoleh total hasil evaluasi.

$$
\begin{aligned}
& \mathrm{WE}=\mathrm{FW} \times \mathrm{E} \\
& \sum \mathrm{WE}=\sum(\mathrm{FW} \times \mathrm{E})
\end{aligned}
$$

Keterangan :

$\mathrm{WE}=$ Weighted Evaluation

FW = Factor Weight

$\mathrm{E}=$ Evaluation 


\section{$\sum \mathrm{WE}=$ Total Weighted Evaluation}

Pada Tabel Raiting Kecocokan Dari Setiap Alternatif Pada Setiap Kriteria diatas, mejelaskan bahwa nilai untuk setiap faktor yang mempengaruhi dalam pengambilan keputusan dari data - data yang akan diproses, nilai yang dimasukkan dalam proses pengambilan keputusan merupakan nilai objektif, yaitu sudah pasti. Dimana nilai rating kecocokan dari setiap alternatif pada tabel 13 diatas beracuan terhadap data pegawai.

Pada tahap berikutnya adalah proses perhitungan nilai weighting evaluation yang merupakan proses perhitungan bobot antara factor weight dan factor evaluation dengan serta penjumlahan seluruh hasil weight evaluations untuk memperoleh total hasil evaluasi.

Tabel 14. Data Alternatif A1

\begin{tabular}{cllll}
\hline Alternatif & Kriteria & Nilai & Nilai Bobot & Hasil \\
\hline \multirow{5}{*}{ A1 } & Kedisiplinan & 50 & 0.3 & 15 \\
& Kerajinan & 100 & 0.25 & 25 \\
& Etika & 100 & 0.25 & 25 \\
& Penilaian Pejabat & 65 & 0.2 & 13 \\
& Jumlah & & & 78 \\
\hline
\end{tabular}

Tabel 15. Data Alternatif A2

\begin{tabular}{cllll}
\hline Alternatif & Kriteria & Nilai & Nilai Bobot & Hasil \\
\hline \multirow{4}{*}{ A2 } & Kedisiplinan & 75 & 0.3 & 22.5 \\
& Kerajinan & 100 & 0.25 & 25 \\
& Etika & 65 & 0.25 & 16.25 \\
& Penilaian Pejabat & 82.5 & 0.2 & 16.5 \\
& Jumlah & & & 80.25 \\
\hline
\end{tabular}

Tabel 16. Data Alternatif A3

\begin{tabular}{cllll}
\hline Alternatif & Kriteria & Nilai & Nilai Bobot & Hasil \\
\hline \multirow{4}{*}{ A3 } & Kedisiplinan & 100 & 0.3 & 30 \\
& Kerajinan & 50 & 0.25 & 12.5 \\
& Etika & 82.5 & 0.25 & 20.625 \\
& Penilaian Pejabat & 100 & 0.2 & 20 \\
& Jumlah & & & 83.125 \\
\hline
\end{tabular}

Berdasarkan hasil nilai preferensi diatas dari A1 s/d A18, maka rangking yang telah diperoleh dapat diurutkan sebagai berikut:

$\begin{array}{ll}\text { W1 } & =78 \\ \text { W2 } & =80.25 \\ \text { W3 } & =83.125 \\ \text { W4 } & =83.75 \\ \text { W5 } & =76.75 \\ \text { W6 } & =84.25 \\ \text { W7 } & =81.625 \\ \text { W8 } & =96.5 \\ \text { W9 } & =93.75 \\ \text { W10 } & =85 \\ \text { W11 } & =96.5 \\ \text { W12 } & =92.125 \\ \text { W13 } & =85.875 \\ \text { W14 } & =89.375 \\ \text { W15 } & =93.75 \\ \text { W16 } & =100 \\ \text { W17 } & =79.375 \\ \text { W18 } & =75 .\end{array}$

Berdasarkan hasil nilai diatas, maka penulis juga menjelaskan secara algoritma sederhananya. Adapun algoritma sederhana terhadap terhitungan diatas antara lain adalah sebagai berikut :

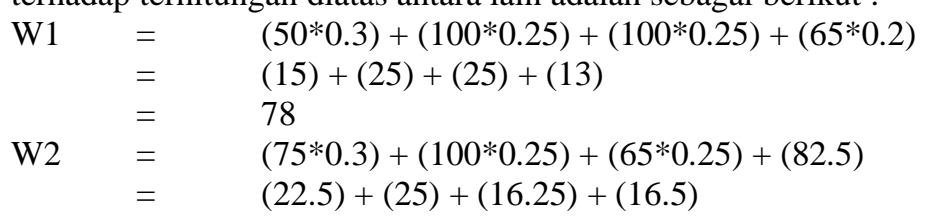




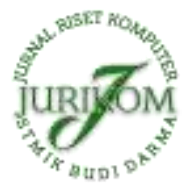

JURIKOM (Jurnal Riset Komputer), Vol. 7 No. 3, Juni 2020 e-ISSN 2715-7393 (Media Online), p-ISSN 2407-389X (Media Cetak) DOI 10.30865/jurikom.v7i3.2171

$$
\begin{array}{rll} 
& = & 80.25 \\
\mathrm{~W} 3 & = & (100 * 0.3)+(50 * 0.25)+(82.5 * 0.25)+(100 * 0.2) \\
& = & (30)+(12.5)+(20.625)+(20) \\
& & 83.125
\end{array}
$$

Untuk perhitungan selanjutnya hingga sampai W18 menggunakan rumus yang sama seperti diatas. Dari perhitungan diatas , maka dapat ditentukan Pegawai Pemerintah Non Pegawai Negeri (PPNPN) terbaik adalah A16 (Budi Setiawan).

Tabel 17. Data Keputusan

\begin{tabular}{ccccccccccc}
\hline Alternatif & C1 & B1 & C2 & B2 & C3 & B3 & C4 & B4 & Hasil & Keputusan \\
\hline A1 & 50 & 0.3 & 100 & 0.25 & 100 & 0.25 & 65 & 0.2 & 78 & Tidak Layak \\
A2 & 75 & 0.3 & 100 & 0.25 & 65 & 0.25 & 82.5 & 0.2 & 80.25 & Tidak Layak \\
A4 & 100 & 0.3 & 50 & 0.25 & 82.5 & 0.25 & 100 & 0.2 & 83.125 & Tidak Layak \\
A5 & 75 & 0.3 & 100 & 0.25 & 65 & 0.25 & 100 & 0.2 & 83.75 & Tidak Layak \\
A6 & 75 & 0.3 & 100 & 0.25 & 65 & 0.25 & 65 & 0.2 & 76.75 & Tidak Layak \\
A7 & 100 & 0.3 & 100 & 0.25 & 65 & 0.25 & 65 & 0.2 & 84.25 & Tidak Layak \\
A8 & 100 & 0.3 & 100 & 0.25 & 82.5 & 0.25 & 30 & 0.2 & 81.625 & Tidak Layak \\
A9 & 100 & 0.3 & 100 & 0.25 & 100 & 0.25 & 82.5 & 0.2 & 96.5 & Tidak Layak \\
A10 & 100 & 0.3 & 75 & 0.25 & 100 & 0.25 & 100 & 0.2 & 93.75 & Tidak Layak \\
A11 & 100 & 0.3 & 75 & 0.25 & 65 & 0.25 & 100 & 0.2 & 85 & Tidak Layak \\
A12 & 100 & 0.3 & 100 & 0.25 & 100 & 0.25 & 82.5 & 0.2 & 96.5 & Tidak Layak \\
A13 & 100 & 0.3 & 100 & 0.25 & 82.5 & 0.25 & 82.5 & 0.2 & 92.125 & Tidak Layak \\
A14 & 100 & 0.3 & 75 & 0.25 & 82.5 & 0.25 & 82.5 & 0.2 & 85.875 & Tidak Layak \\
A15 & 100 & 0.3 & 75 & 0.25 & 82.5 & 0.25 & 100 & 0.2 & 89.375 & Tidak Layak \\
A16 & 100 & 0.3 & 75 & 0.25 & 100 & 0.25 & 100 & 0.2 & 93.75 & Layak \\
A17 & 100 & 0.3 & 100 & 0.25 & 100 & 0.25 & 100 & 0.2 & 100 & Tidak Layak \\
A18 & 75 & 0.3 & 100 & 0.25 & 47.5 & 0.25 & 100 & 0.2 & 79.375 & Tidak Layak \\
\hline
\end{tabular}

\subsection{Implementasi}

Dari hasil implementasi pengujian yanng dilakukan pada Sistem Pendukung Keputusan Pemilihan Pegawai Pemerintah Non Pegawai Negeri (PPNPN) Terbaik Pada Kantor Imigrasi Kelas I Poloniamedan Menerapkan Metode Multifaktor Evaluation Process (MFEP) adalah sebagiai beriku:

1. Form Menu Utama

Form menu utama adalah form antar muka (interface) yang digunakan sebagai form induk atau form utama. Form menu utama akan ditampilkan setelah user melakukan proses login. Untuk lebih jelasnya dapat dilihat pada gambar dibawah ini.

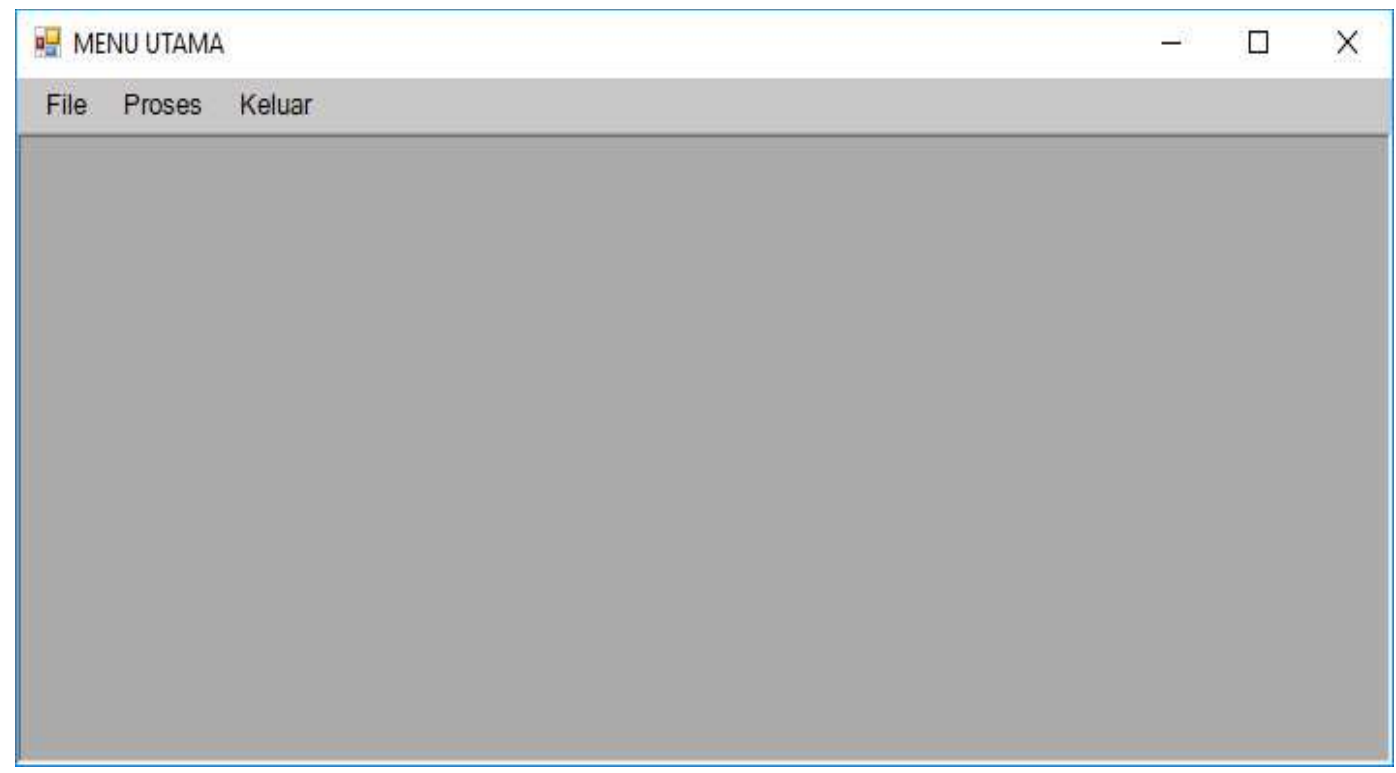

Gambar 1. Form menu utama

2. Form Alternatif

Form alternatif digunakan untuk menginputkan data kriteria dan menyimpannya ke dalam database. Untuk lebih jelasnya dapat dilihat pada gambar berikut ini. 


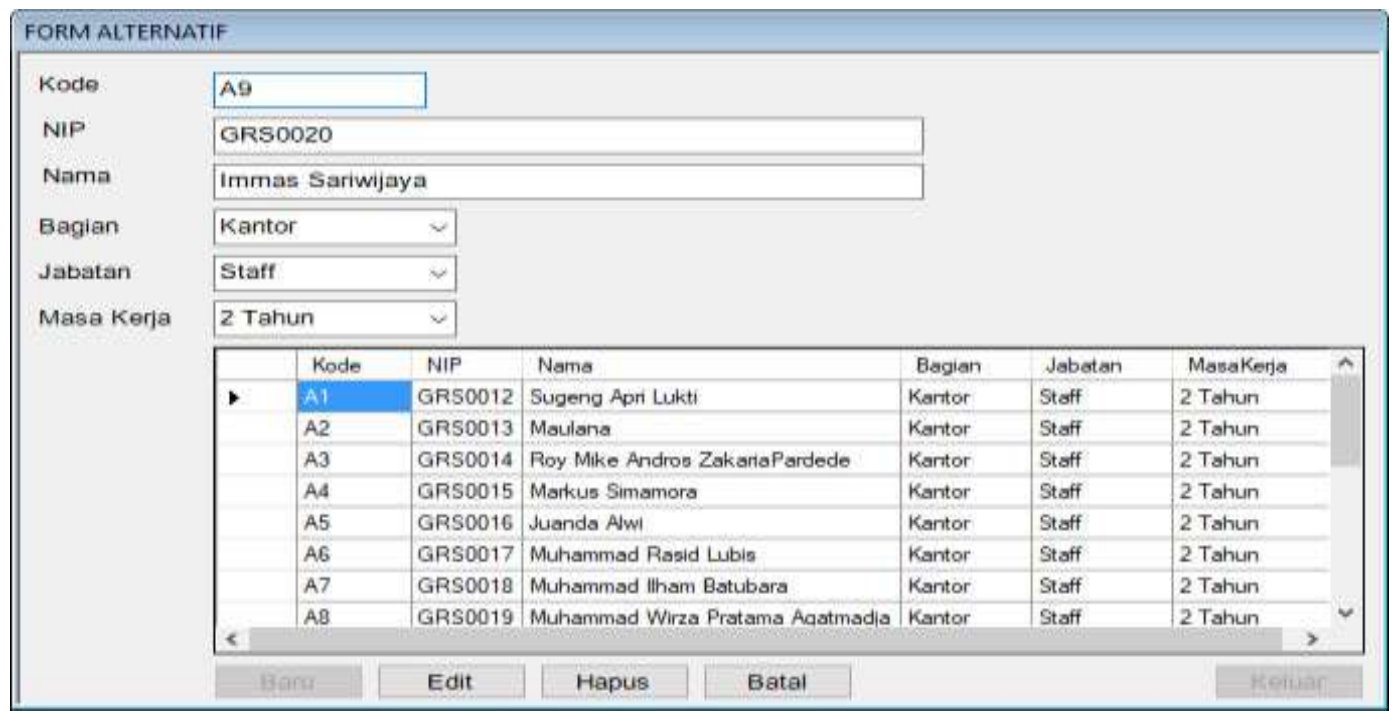

Gambar 2. Form alternatif

3. Form Kriteria

Form kriteria digunakan untuk menginputkan data kriteria dan bobot dari kriteria serta menyimpannya ke dalam database. Untuk lwbih jelasnya dapat dilihat pada gambar dibawah ini.

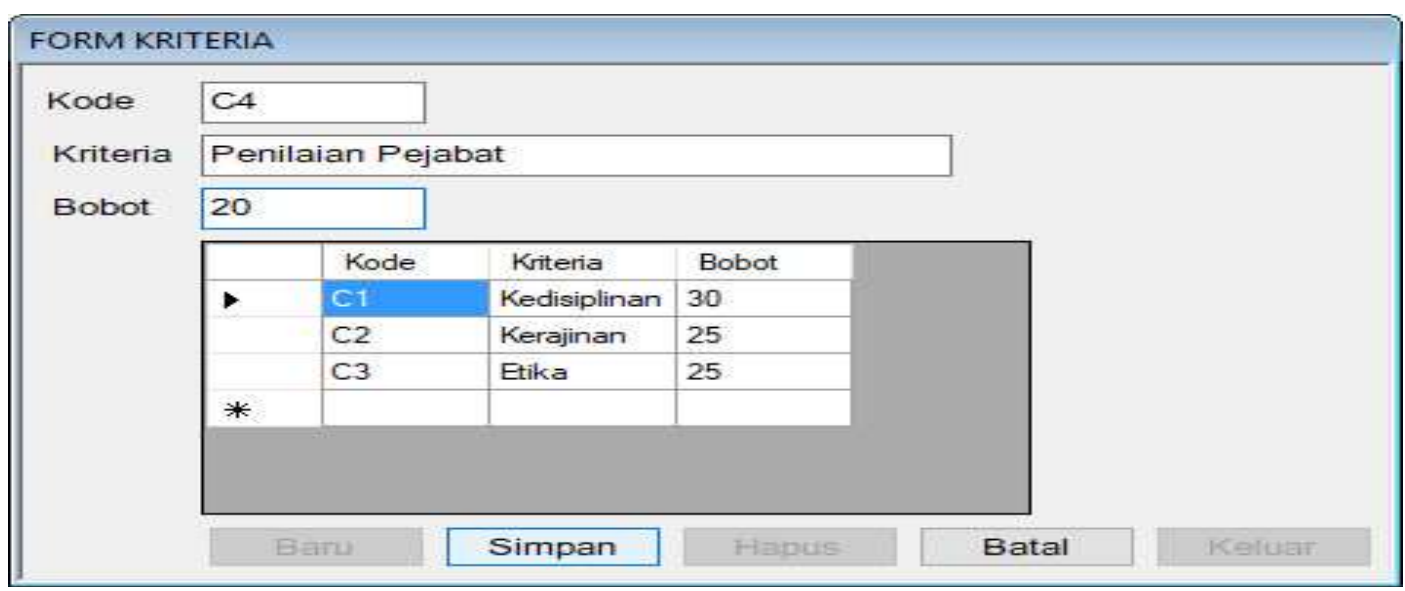

Gambar 3. Form kriteria

4. Form Rating Kecocokan

Form rating kecocokan digunakan untuk menginputkan data nilai alternatif utuk setiap kriteria dan menyimpannya ke dalam database. Untuk lebih jelasnya dapat dilihat pada gambar berikut ini.

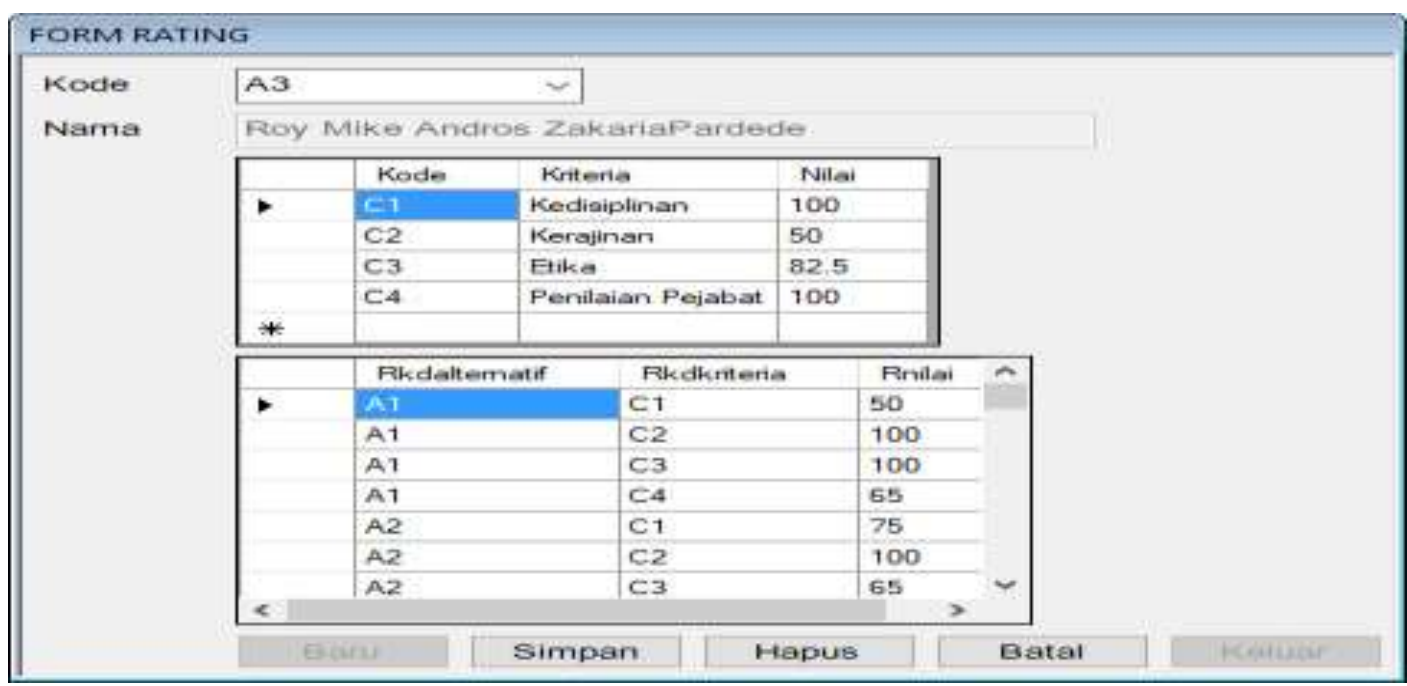

Gambar 4. Form rating kecocokan 
5. Form Hasil Keputusan

Form hasil keputusan merupakan form untuk menampilkan hasil keputusan yang akan menjadi alternatif terbaik pada proses seleksi calon taruna pramugara pada Aerospace Training Centre. Untuk lebih jelasnya dapat dilihat pada gambar dibawah ini.

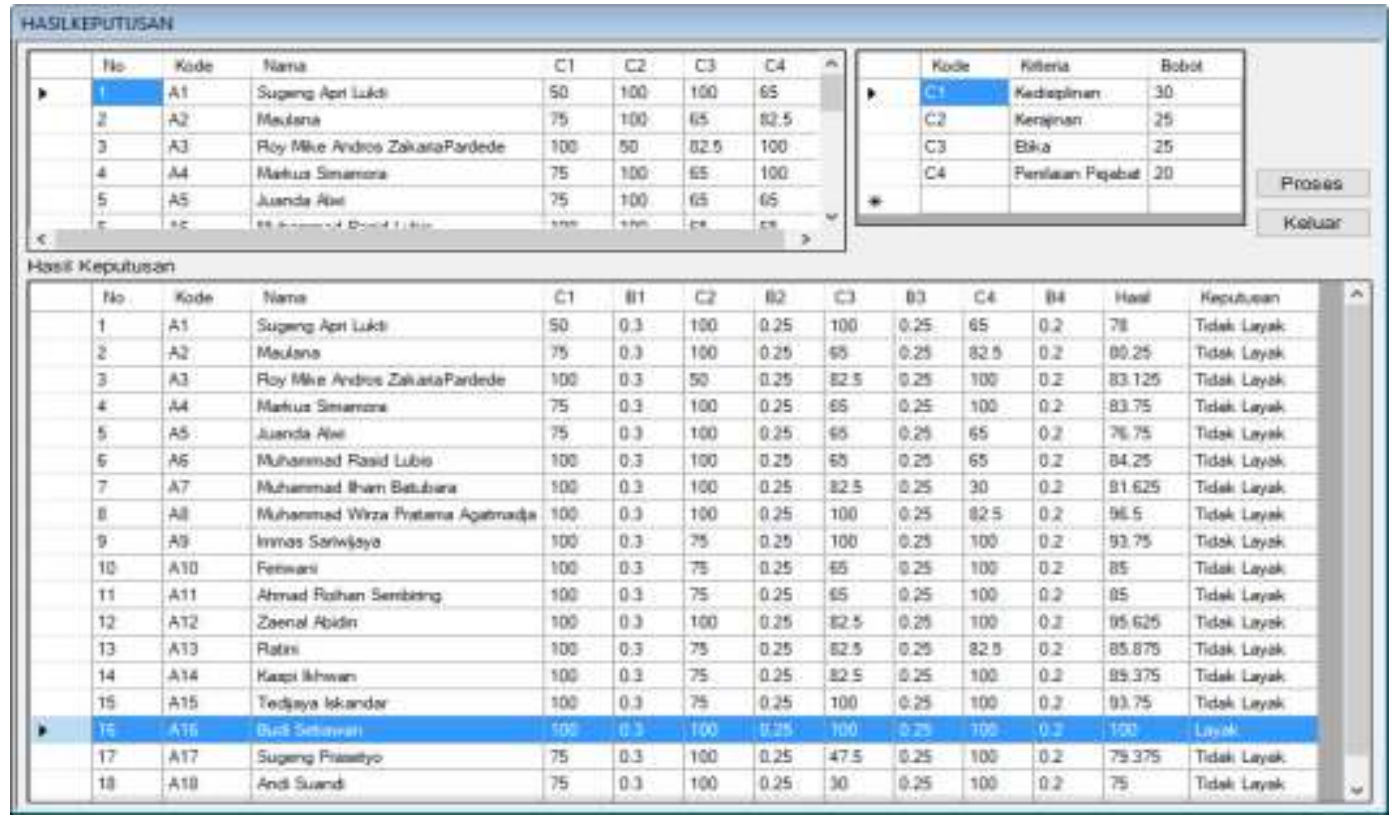

Gambar 5. Form hasil keputusan

Berdasarkan hasil pengujian sistem diatas, maka diperoleh dari pada gambar 5. sistem menyatakan bahwa A16 (Budi Setiawan) yang layak terpilih sebagai Pegawai Pemerintah Non Pegawai Negeri (PPNPN) terbaik pada kantor imigrasi kelas I polonia..

\section{KESIMPULAN}

Berdasarkan pembahasan dari penelitian mengenai pemilihan Pegawai Pemerintah Non Pegawai Negeri (PPNPN) terbaik pada kantor imigrasi kelas I polonia, maka diperoleh kesimpulan sebagai berikut:

1. Metode Multifactor Evaluation Process (MFEP) dapat ditentukan urutan prioritas dalam perhitungan multikriteria.

2. Penerapan kriteria kedisiplinan, kerajinan, etika dan penilaian pejabat dapat membantu dalam pemilihan Pegawai Pemerintah Non Pegawai Negeri (PPNPN) terbaik pada kantor imigrasi kelas I polonia.

3. Sistem pendukung keputusan dengan menerapkan metode Multifactor Evaluation Process (MFEP), maka kantor imigrasi kelas I polonia dapat memperoleh alternatif yang tepat dalam menentukan Pegawai Pemerintah Non Pegawai Negeri (PPNPN) terbaik.

\section{REFERENCES}

[1] I. Afrianty and R. Umbara, "Sistem Pendukung Keputusan (SPK) Menentukan Kelayakan Calon Penerima Zakat Menerapkan MultiFactor Evaluation Process (MFEP),” Semin. Nas. Teknol. Inf., no. November, pp. 87-94, 2016.

[2] R. Turaina and C. Gustia E, "Sistem Penunjang Keputusan Penerimaan Calon Tenaga Honorer Di Sma N 1 Junjung Sirih Kab. Solok Menggunakan Metode Multifaktor Evaluasi Proses (Mfep),” J. Momentum, vol. 18, no. 2, pp. 60-66, 2016.

[3] T. Limbong et al., Sistem Pendukung Keputusan: Metode \& Implementasi. Medan: Yayasan Kita Menulis, 2020.

[4] S. Kusumadewi, S. Hartati, A. Harjoko, and Retantyo Wardoyo, Fuzzy Multi-Attribute Decision Making (FUZZY MADM). 2006.

[5] T.-P. Turban, E., Aronson, J., \& Liang, Decision Support Systems And Inteligence System. US: Prentice-Hall, 2005.

[6] D. Nofriansyah, Konsep Data Mining Vs Sistem Pendukung Keputusan. 2015.

[7] Kusrini, Konsep dan Aplikasi Sistem Pendukung Keputusan. 2007.

[8] M. Untuk, P. Guru, S. Kasus, and M. A. N. Kota, "Multifactor evaluation process,” no. April, pp. 76-79, 2017. 